\title{
Usefulness of the ALSAQ-5 scale in evaluation of quality of life in amyotrophic lateral sclerosis
}

\section{Przydatność skali ALSAQ-5 w ocenie jakości życia w stwardnieniu zanikowym bocznym}

\author{
Monika Gołąb-Janowska', Krystyna Honczarenko', Jan Stankiewicz² \\ ISamodzielny Publiczny Szpital Kliniczny nr I, Katedra i Klinika Neurologii, Pomorski Uniwersytet Medyczny w Szczecinie \\ 20ddział Neurologii, Samodzielny Publiczny Wojewódzki Szpital Zespolony w Szczecinie
}

Neurologia i Neurochirurgia Polska 2010; 44, 6: 560-566

\begin{abstract}
Background and purpose: The evaluation of quality of life (QoL) is one of the most important factors in complex care of patients. The aim of the study was to estimate the usefulness of the shortened QoL-evaluating scale ALSAQ-5 in patients with amyotrophic lateral sclerosis and to establish the relationship between QoL and age, sex, duration of the disease, education and treatment.
\end{abstract}

Material and methods: Forty-four patients (24 males and 20 females) aged between 34 and 81 years (mean 58.9) were studied. The QoL was evaluated with the ALSAQ-40 and ALSAQ-5 scales. Patients could score between 0 and 100 pts in both scales (higher score denotes worse QoL). MannWhitney U-test, Wilcoxon test, Kolmogorov-Smirnov test and Spearman rank correlation coefficient were used for statistical analysis.

Results: The QoL was worsened by limited physical mobility (ALSAQ-40: 22.5-100 pts, mean 80.8; ALSAQ-5: 25-100 pts, mean 88.6), reduced daily living/independence (ALSAQ-40: 7.5-100 pts, mean 76.0; ALSAQ-5: 0-100 pts, mean 75), communication disturbances (ALSAQ-40: 17.9100 pts, mean 75.2; ALSAQ-5: 0-100, mean 73.9), and emotional functioning (ALSAQ-40: 5-100 pts, mean 64.9; ALSAQ-5: 0-100, mean 73.9). Eating and drinking dysfunctions (ALSAQ-40: 0-100 pts, mean 66.3; ALSAQ-5: 0-100, mean 67) had a smaller influence on QoL.

Conclusions: Initial analysis shows that ALSAQ-5 is a sensitive and reliable instrument for the estimation of QoL of

\section{Streszczenie}

Wstęp i cele pracy: Ocena jakości życia (JŻ), ważnego miernika zdrowia, wyznacza najważniejsze cele badań w kompleksowej opiece nad pacjentem. Celem pracy była ocena przydatności skróconej skali oceny JZ - ALSAQ-5 - u chorych na stwardnienie zanikowe boczne oraz ocena zależności JŻ od wieku, płci, czasu trwania choroby, wykształcenia i stosowania leczenia.

Materiał i metody: Badaniu poddano 44 pacjentów (24 mężczyzn i 20 kobiet) w wieku 34-81 lat (średnia wieku: 58,9 roku). Jakość życia oceniano za pomocą skal ALSAQ-40 i ALSAQ-5. W każdej z nich chory mógł uzyskać od 0 do 100 pkt (większa liczba punktów oznacza gorszą jakość życia). Do analizy statystycznej użyto testów $U$ Manna-Whitneya, Wilcoxona dla par związanych, Kołmogorowa-Smirnowa i współczynnika korelacji rang Spearmana.

Wyniki: Jakość życia okazała się być zaburzona głównie poprzez ograniczenia wynikające z pogorszenia aktywności fizycznej (ALSAQ-40: 22,5-100, średnia: 80,8; ALSAQ-5: 25-100, średnia: 88,6), ograniczenia codziennych czynności/utrata niezależności (ALSAQ-40: 7,5-100, średnia: 76,0; ALSAQ-5: 0-100, średnia: 79,5), zaburzenia komunikacji werbalnej (ALSAQ-40: 17,9-100, średnia: 75,2; ALSAQ-5: 0-100, średnia: 75) i funkcjonowania emocjonalnego (ALSAQ-40: 5-100, średnia: 64,9; ALSAQ-5: 0-100, średnia: 73,9). Dysfunkcje jedzenia i picia (ALSAQ-40: 0-100, średnia: 66,3; ALSAQ-5: 0-100, średnia: 67) w mniejszym stopniu wpływały na J̇̈.

Correspondence address: dr n. med. Monika Gołąb-Janowska, Katedra i Klinika Neurologii PUM, ul. Unii Lubelskiej 1, 71-252 Szczecin, e-mail:monikagi@op.pl

Received: 3.03.2010; accepted: 27.07.2010 
patients with amyotrophic lateral sclerosis. As there are no statistical differences in QoL estimation using ALSAQ-40 and ALSAQ-5, ALSAQ-5 seems to be more useful in clinical practice.

Key words: quality of life, ALSAQ-5 scale, amyotrophic lateral sclerosis.
Wnioski: Wstępne analizy wskazują, że ALSAQ-5 jest czułym i wiarygodnym miernikiem JŻ chorych na stwardnienie zanikowe boczne. Wobec braku istotnych różnic statystycznych w ocenie JŻ przy zastosowaniu skali ALSAQ-40 i ALSAQ-5 wydaje się, że w praktyce klinicznej większe znaczenie może mieć skala ALSAQ-5.

Słowa kluczowe: jakość życia, skala ALSAQ-5, stwardnienie zanikowe boczne.

Everybody wants to live well (...) to get what is needed, to be respected and loved. Everybody wants to take pleasure and satisfaction from his or her activities. Can we assess or measure the way we live? Should we?

W. Ostasiewicz

\section{Introduction}

Quality of life (QoL) is an equivocal term dependent on cultural, moral and general social standards and conditioned by multiple factors.

According to the World Health Organization, QoL is defined as individuals' perceptions of their position in life in the context of the culture and value systems in which they live and in relation to their goals, expectations, standards and concerns [1].

Most QoL concepts consider two dimensions: objective and subjective. The first is related to physical, psychological, social and cognitive functioning; the second appeals to the sense of satisfaction and individual assessment of life as a whole or in particular domains [2].

The improvements in therapy and medical technology, as well as longer life expectancy with the inevitable increase in number of chronically ill patients, are the major contributors to the special importance of QoL-related problems in most countries. Assessment of QoL in medicine assumes that the health status significantly affects the functioning of the individual in the psychophysical and social domain, as well as the state of the individual's needs and ambitions; thus, the health status influences QoL both in objective and subjective terms [2].

Quality of life assessment as the major measure of health status has become therefore the domain not only of sociologists, pedagogues and psychologists, but also of physicians. This assessment guides most important goals of all activities related to the complex care of the patient [3-8].

The first reports on QoL were published by American experts in the 1960s but the major importance of
QoL in chronically ill patients, including neurological ones, was highlighted in the last two decades [3-5,9-14].

Amyotrophic lateral sclerosis (ALS), thoroughly described in its clinical aspects by Charcot in 1874, is still one of the most important challenges in clinical neurology. This rare neurodegenerative disease (with the incidence of 4-5/100 000 in our latitude) that progressively affects both upper and lower motor neurons is a major clinical problem. Individual patients are engraved in the physician's memory due to the progressive course and therapeutic helplessness $[4,5,7,15,16]$.

The QoL in patients with ALS may be evaluated with general questionnaires and those more specific for the disease. The latter ones have the advantage of covering those domains which are different or specifically altered in the course of ALS [3,11,17-19].

The questionnaires widely used to evaluate $\mathrm{QoL}$ in patients with ALS include several general measures the Appel Scale, Short Form Health Survey (SF-36), McGill Quality of Life Questionnaire, Sickness Impact Profile (SIP), Tufts Quantitative Neuromuscular Exam (TQNE), and more detailed ones - the Norris ALS Scale, ALS Functional Rating Scale (ALSFRS) and its modification, the Revised ALSFRS, and the 40-item Amyotrophic Lateral Sclerosis Assessment Questionnaire (ALSAQ-40) [3,9,11,20-22]. These QoL measures are sensitive and commonly used in research but less useful in clinical practice due to the comprehensive structure and time-consuming evaluation.

ALSAQ-40, a subjective 40-item questionnaire developed especially for the assessment of the domains particularly important for ALS patients, is a good exam- 
ple of a sensitive and reliable QoL measure commonly used in research $[14,18,22]$. Five-item Amyotrophic Lateral Sclerosis Assessment Questionnaire (ALSAQ-5) was subsequently created by extracting one item from each domain. The choice of item was guided by the result of assessment that was most similar to the result of assessment in the whole domain. The preliminary studies suggested that ALSAQ-5 provided a reliable measure of QoL in patients with ALS.

Due to its simple structure, ALSAQ-5 might be useful in surveys and other studies, as well as in clinical practice, as it is troublesome neither for investigators nor for this particular group of patients [18].

The great reliability confirmed for ALSAQ-40 suggests that the domains included in that questionnaire are related to the crucial and most important problems for ALS patients; the close relationship between ALSAQ-40 and ALSAQ-5 results suggests that the latter provides similar insight into the QoL in ALS patients.

Jenkinson et al. [11] suggest that ALSAQ-5 enables brief evaluation of QoL in patients with ALS, which is closely concordant with ALSAQ-40. They believe that ALSAQ-5 might be the measure of choice in situations in which ALSAQ-40 is less practical [19]. There are some suggestions that ALSAQ-5 might be a useful addition to the clinical assessment of the patient's status in everyday practice, similarly to the COOP Charts [23]. The COOP Charts are a short measure of QoL containing eight items, addressing health-related QoL.

The Dartmouth Primary Care COOP Project suggests that this short form might be distributed among out-patients who are waiting for a visit. Patients would answer the questionnaire and give the filled form to the physician. It might help the treating physician to obtain greater knowledge about specific patient problems and improve communication as well as the patient-health care professional relationship [23]. It is plausible that ALSAQ-5 might have similar use.

Polish language lacks valuable diagnostic tools developed with the current standards of care.

The authors came to the conclusion that the complexity and importance of problems related to the disease might influence the QoL; its assessment might help in finding out about the most important ones.

The aim of the study was to estimate the usefulness of the shortened QoL evaluating scale ALSAQ-5 in patients with ALS and to establish the relationship between QoL and age, sex, duration of the disease, education and treatment.
The authors assumed that the satisfactory results of the study would be followed by the adaptation of the questionnaire - the factorial analysis, checking the reliability and validity for the Polish version of the measure with good psychometric properties. The authors plan to assess psychometric properties of the scales and to establish normative values among a representative population sample.

\section{Material and methods}

The study included 44 patients diagnosed with ALS according to the current diagnostic criteria proposed by the European Federation of Neurological Societies and covering the diagnosis and management of patients with ALS [15]. The study group included 24 men (54.5\%) and 20 women (45.5\%) aged between 34 and 81 (mean: 58.9) who were treated in the out-patient clinic for neurodegenerative disorders or were admitted to the Department of Neurology (Pomeranian Medical University, head: Prof. Przemysław Nowacki) or to the Neurological Ward in the Voivodship Hospital in Szczecin (head: Dr Jan Stankiewicz).

Participation in the study was voluntary and anonymous. Patients received general information regarding aim, type and duration of the study, which was performed separately for each patient and used the same conditions. Exclusion criteria comprised doubts whether the patient was able to fully understand the instructions how to fill in the questionnaire or inability to self-complete the questionnaire. Patients responded to two parts of the questionnaire: the first one covered personal information (age, sex, duration of the disease, education level, treatment used); the second part contained two analytical questionnaires with detailed questions related to the influence of ALS on QoL (ALSAQ-40 and ALSAQ-5).

ALSAQ-40 and ALSAQ-5 were developed by Jenkinson et al. [14]. This specific tool for the assessment of QoL has been widely studied in terms of validity and reliability among patients diagnosed with ALS living in England, Wales, and Northern Ireland [14]. Good psychometric properties of the scale were confirmed in Italian [13] and Spanish [22] populations. ALSAQ-40 contains 40 items grouped into 5 five areas: Physical Mobility (walking, standing, going up and down the stairs), Activities of Daily Living and Independence (washing, dressing, writing, doing jobs around the house), Eating and Drinking (eating solid food, drinking, swallowing), Communication and Emotional Functioning (feeling lonely or depressed). Each item is scored from 0 to 4 according to 
the frequency of a particular problem $(0-$ never, 1 - rarely, 2 - sometimes, 3 - often, 4 - always).

The score for each domain is between 0 and 100; it enables comparison with other domains and provides a simple interpretation of results $(0-$ the best $\mathrm{QoL}$ in aspects covered by the questionnaire, 100 - the worst $\mathrm{QoL})$. The first four domains are related to the influence of neurological deficits and related disability on the QoL. The fifth domain is related to the emotional problems subsequent to the response to the physical impairment [14].

The ALSAQ-5 questionnaire consists of 5 items derived from ALSAQ-40; each item represents one domain [14].

The authors of the original questionnaires were contacted and permission was obtained to use the questionnaires for that purpose. The questionnaires were translated (according to the generally accepted principles) by a team of translators and specialists in neurology, having expertise in the area of QoL. Translations were compared and the small differences in translations were discussed. Then, an independent bilingual person performed back-translation, with the subsequent correction of the differences in those Polish elements that were divergent from the original ones.

The results of ALSAQ-40 and ALSAQ-5 were interpreted according to the rules presented in Table 1.

The results of $\mathrm{QoL}$ assessments were correlated with age, sex, duration of the disease, education (coded for statistical purposes as: 0 - elementary, 1 - vocational, 2 - secondary, and 3 - university) and the treatment used.

Variables had skewed distribution. Statistical analysis involved Mann-Whitney $U$-test, Wilcoxon test for paired samples, Kolmogorov-Smirnov test and Spear- man rank correlation coefficient. A $p$-value $<0.05$ was considered significant.

\section{Results}

Duration of the disease among studied patients ranged from 1.5 to 4 years (mean: 2.36).

Sixteen patients (36.4\%) received a vocational education, 14 patients $(31.8 \%)$ elementary education, 10 patients $(22.7 \%)$ secondary education, and 4 (9.1\%) patients had a university degree.

Only 12 patients $(27.3 \%)$ were treated with riluzole.

The results of ALSAQ-40 suggested that QoL in patients with ALS was disturbed mainly due to the limitations related to worsened physical mobility (mean score: 80.8), restrictions in activities of daily living and independence (mean score: 76.0), communication (mean score: 75.2), emotional functioning (mean score: 64.9) and finally, eating and drinking (66.3). Similar results (mean score: 88.6, 79.5, 75, 73.9 and 67, respectively) were obtained with ALSAQ-5. The assessments in both scales did not differ significantly (Table 2).

Table 1. Interpretation of score ranges for dimensions on the ALSAQ-40 and ALSAQ-5

\begin{tabular}{|ll|}
\hline Score range & Interpretation \\
\hline $0-19$ & no problems \\
\hline $20-39$ & problems rarely \\
\hline $40-59$ & problems sometimes \\
\hline $60-79$ & problems often \\
\hline $80-100$ & $\begin{array}{l}\text { problems always/nearly always or unable } \\
\text { to do at all }\end{array}$ \\
\hline ALSAO-Amyotrophic Lateral Sclerosis Assessment Ouestionnaire
\end{tabular}

ALSAQ - Amyotrophic Lateral Sclerosis Assessment Questionnaire

Table 2. Results of ALSAQ-40 and ALSAQ-5 items

\begin{tabular}{|c|c|c|c|c|}
\hline & Mean (SD) & Median & Range & $\begin{array}{c}\text { Upper-lower } \\
\text { quantile }\end{array}$ \\
\hline Physical Mobility ALSAQ-40 & $80.8(21.85)$ & 83.8 & $22.5-100$ & $70-100$ \\
\hline Physical Mobility ALSAQ-5 & $88.6(22.79)$ & 100 & $25-100$ & $100-100$ \\
\hline Daily living/Independence ALSAQ-40 & $76(27.9)$ & 85 & $7.5-100$ & $67.5-100$ \\
\hline Daily living/Independence ALSAQ-5 & $79.5(33.31)$ & 100 & $0-100$ & $75-100$ \\
\hline Eating and Drinking ALSAQ-40 & $66.3(35.86)$ & 79.2 & $0-100$ & $33.3-100$ \\
\hline Eating and Drinking ALSAQ-5 & $67.0(40.38)$ & 87.5 & $0-100$ & $25-100$ \\
\hline Communication ALSAQ-40 & $75.2(27.67)$ & 83.9 & $17.9-100$ & $42.9-100$ \\
\hline Communication ALSAQ-5 & $75.0(30.86)$ & 87.5 & $0-100$ & $50-100$ \\
\hline Emotional Functioning ALSAQ-40 & $64.9(27)$ & 63.8 & $5-100$ & $50-90$ \\
\hline Emotional Functioning ALSAQ-5 & $73.9(33.16)$ & 87.5 & $0-100$ & $50-100$ \\
\hline
\end{tabular}

ALSAQ - Amyotrophic Lateral Sclerosis Assessment Questionnaire; SD - standard deviation 
Table 3. Statistical correlation between results obtained with ALSAQ-40 and ALSAQ-5

\begin{tabular}{|lcc|}
\hline & $\boldsymbol{r}$ & p-value \\
\hline Physical Mobility & 0.71 & 0.0002 \\
\hline Daily Living/Independence & 0.74 & 0.0001 \\
\hline Eating and Drinking & 0.94 & $<0.0001$ \\
\hline Communication & 0.90 & $<0.0001$ \\
\hline Emotional Functioning & 0.83 & $<0.0001$ \\
\hline
\end{tabular}

ALSAQ - Amyotrophic Lateral Sclerosis Assessment Questionnaire

$r$-Spearman rank correlation coefficient

The results in each of the five domains in ALSAQ-40 and ALSAQ-5 were highly correlated. The strongest correlation, almost a complete one, was noted for the Eating and Drinking and the Communication domains (Table 3).

The scores in the Physical Mobility domain, in both ALSAQ-40 and ALSAQ-5, suggested significantly worse QoL in low-educated patients (Table 4). No such association was found between level of education and other domains in both scales. QoL was not associated with age $(p>0.08)$ or duration of the disease $(p>0.13)$. Neither sex $(p>0.06)$ nor treatment $(p>0.08)$ affected the QoL.

\section{Discussion}

Amyotrophic lateral sclerosis has a marked negative impact on QoL of patients due to the progressive relentless course, incurable character of the disorder and, on top of that, the marked impairment of activities of daily living $[5,10,14,16,17,19-22]$.

The assessment of QoL perceived by chronically ill patients recently became important for the improvement of care and for better understanding of the problem [5,9-12,14-19]. Until recently, the attempts to evaluate the impact of QoL in patients with ALS were based on clinical observations and classification of particular symptoms and signs of the disease [16]. The major disadvantage of that approach was the subjective opinion of the investigator rather than the patient's complaints. The development of methods used in assessment of QoL in various medical disciplines, including neurology, seen in the last decade enabled a better insight into the influence of the disease on the patient's life. The use of different scales for QoL assessment, on the other hand, makes comparisons difficult or impossible.
Table 4. Correlation between education and results obtained with ALSAQ-40 and ALSAQ-5

\begin{tabular}{|lcccc|}
\hline & \multicolumn{2}{c}{ ALSAQ-40 } & \multicolumn{2}{c|}{ ALSAQ-5 } \\
\hline & $\boldsymbol{r}$ & $\mathbf{p}$-value & \multicolumn{1}{c|}{$\boldsymbol{\boldsymbol { r }}$} & $\mathbf{p}$-value \\
\hline Physical Mobility & -0.43 & 0.04 & -0.49 & 0.02 \\
\hline Daily Living/Independence & -0.06 & 0.79 & -0.22 & 0.31 \\
\hline Eating and Drinking & -0.07 & 0.76 & +0.01 & 0.96 \\
\hline Communication & -0.24 & 0.28 & -0.12 & 0.58 \\
\hline Emotional Functioning & -0.13 & 0.55 & +0.05 & 0.80 \\
\hline $\begin{array}{l}\text { ALSAQ-Amyotrophic Lateral Sclerosis Assessment } \\
\text { r-Spearman rank correlationnaire coefficient }\end{array}$ & & & \\
\hline
\end{tabular}

Consequently, it is difficult to achieve adequate knowledge on those aspects of the disease that affect QoL most importantly.

It seems that clinical practice might benefit from disease-specific questionnaires because they cover areas disturbed in particular disorders and register problems and difficulties of those particular patients. ALSAQ-40, with its good psychometric properties, is an excellent example of that type of instrument $[14,18,22]$. ALSAQ-5, the shorter version of ALSAQ-40, also provides reliable information on QoL in ALS patients, as reported in preliminary studies [11]. Jenkinson et al. [11] suggest that ALSAQ-5 provides a concise assessment of the impact of ALS on QoL, and this assessment is closely concordant with the results of ALSAQ-40.

Our study showed a significant association between ALSAQ-40 and ALSAQ-5 in assessment of each tested domain, with high correlation coefficient $(r)$ values. The QoL in patients with ALS is impaired mainly due to the worse physical mobility but also due to the limitations in activities of daily living and independence, worse communication and emotional problems. Difficulties in eating and drinking affect the QoL of these patients to a lesser extent.

Our results are in agreement with those obtained by Jenkinson et al. [11], who also reported major worsening of QoL due to the physical mobility restrictions and limitations in activities of daily living and independence.

Some studies suggest that patients with ALS may experience high QoL despite their major physical disability $[9,21]$. Lule et al. [21] did not find any association between QoL in ALS patients and the physical disability that developed during the course of the disease. Roach et al. [20] argue that low QoL in ALS patients might be unrelated to the influence of the dise- 
ase itself but rather due to the idiosyncratic factors, as exemplified by the lack of influence of disease progression on the well-being of patients.

Some authors report weak or no correlation between QoL and the level of disability or the duration of the disease [20]. Our study also did not show a relationship between QoL and duration of the disease.

We could not find any information related to the possible association between QoL in ALS patients and their age, sex, level of education or treatment. Our results indicated a significant association between the physical mobility domain of QoL and the level of education.

The convenience for the investigator and the decreased burden for the patient due to the use of ALSAQ-5 in the assessment of QoL suggest that it is more useful in routine clinical practice.

We believe that further studies on QoL with ALSAQ-5 are needed to evaluate its reliability for QoL assessment and the usefulness of obtained data.

The continued validation process of the Polish versions of the QoL questionnaires gives an opportunity for objective assessment of the influence of the disease on $\mathrm{QoL}$ and provides a tool for comparison of various types of management in relation to QoL.

\section{Conclusions}

1. Preliminary analyses suggest that ALSAQ-5 is a sensitive and reliable measure of QoL in patients with ALS.

2. Lack of significant statistical differences in the assessment of QoL between ALSAQ-40 and ALSAQ-5 suggests that ALSAQ-5 might be more useful in clinical practice.

\section{Acknowledgement}

The authors would like to thank Dr hab. n. med. Krzysztof Safranow for his statistical expertise.

\section{Disclosure}

The authors report no conflict of interest.

\section{References}

1. The WHOQOL Group. The development of the World Health Organization quality of life assessment instrument (the WHOQOL). In: Orley J., Kuyken W. [eds.]. Quality of life assessment: international perspectives. Springer Verlag, Heidelberg. 1994.
2. Sęk H. Pojęcie normy, normalności i zdrowia. In: Sęk H. Psychologia kliniczna. Wydaronictwo Naukowe PWN, Warszawa 2005, pp. 55-64.

3.Bromberg M.B, Anderson F., Davidson M., et al. Assessing health status quality of life in ALS: comparison of the SIP/ALS19 with the ALS Functional Rating Scale and the Short Form12 Health Survey. ALS C.A.R.E. Study Group. Clinical Assessement, Research, and Education. Amyotroph Lateral Scler Other Motor Neuron Disord 2001; 2: 31-37.

4. Jenkinson C., Swash M., Fitzpatrick R. The European Amyotrophic Lateral Sclerosis Health Profile Study. ALS-HPS Steering Group. J Neurol Sci 1998; 160: 122-126.

5. Jenkinson C. Quality of life in ALS. Amyotroph Lateral Scler Other Motor Neuron Disord 2000; 1: 223-224.

6. Tracy J.I., Dechant V., Sperling M.R., et al. The association of mood with quality of life ratings in epilepsy. Neurology 2007; 68: 1101-1107.

7. Borasio G.D. Palliative care in ALS: searching for the evidence base. Amyotroph Lateral Scler Other Motor Neuron Disord 2001; 2: 31-35.

8. Nelson E.C., Landgraf J.M., Wasson J.H., et al. The functional status of patients: How can it be measured in physicians' offices? Med Care 1990; 28: 1111-1126.

9. Bromberg M. Quality of life in amyotrophic lateral sclerosis. Phys Med Rehabil Clin N Am 2008; 19: 591-605.

10. Gelinas D.F., O'Connor P., Miller R.G. Quality of life for ventilator-dependent ALS patients and their caregivers. $J$ Neurol Sci 1998; 160: 134-136.

11. Jenkinson C., Fitzpatrick R., Garratt A., et al. Can item response theory reduce patient burden when measuring health status in neurological disorders? Results from Rasch analysis of the SF-36 physical functioning scale (PF-10). J Neurol Neurosurg Psychiatry 2001; 71: 220-224.

12. Swash M. Health outcome and quality-of-life measurements in amyotrophic lateral sclerosis. J Neurol 1997; 244: 26-29.

13. Palmieri A., Sorraru G., Lombardi L., et al. Quality of life and motor impairment in ALS: Italian validation of ALSAQ. Neurol Res 2010; 32: 32-40.

14. Jenkinson C., Fitzpatrick R., Swash M., et al. ALSAQ user manual. Amyotrophic lateral sclerosis assessment questionnaire. Health Service Research Unit University Oxford, Oxford 2001.

15. Andersen P.M., Borasio G.D., Dengler R., et al. EFNS task force on management of amyotrophic lateral sclerosis: guidelines for diagnosing and clinical care of patients and relatives. Eur J Neurol 2005; 12: 921-938.

16. Jenkinson C., Fitzpatrick R., Swash M., et al. The ALS Health Profile Study: quality of life of amyotrophic lateral sclerosis patients and carers in Europe. J Neurol 2000; 247: 835-840.

17. Jenkinson C., Fitzpatrick R., Swash M. Amyotrophic lateral sclerosis/motor neurone disease. In: Jenkinson C., Fitzpatrik R., Jenkinson D. [eds.]. Health status measurement in neurological disorders. Radcliffe Medical Press, Oxford 2000.

18. Jenkinson C., Fitzpatrick R., Brennan C., et al. Development and validation of a short measure of health status for individuals with amyotrophic lateral sclerosis/motor neurone disease: the ALSAQ-40.J Neurol 1999; 246: 16-21. 
19. Jenkinson C., Fitzpatrick R. Reduced item set for the amyotrophic lateral sclerosis assessment questionnaire: development and validation of the ALSAQ-5.J Neurol Neurosurg Psychiatry 2001; 70: 70-73

20. Roach A.R., Averill A.J., Segerstrom S.C., et al. The dynamics of quality of life in ALS patients and caregivers. Ann Behav Med 2009; 37: 197-206.

21. Lule D., Hacker S., Ludolph A., et al. Depression and quality of life in patients with amyotrophic lateral sclerosis. Dtsch Arztebl Int 2008; 105: 397-403.

22. Salas T., Mora J., Esteban J., et al. Spanish adaptation of the amyotrophic lateral sclerosis questionnaire ALSAQ-40 for ALS patients. Amyotrophic Lateral Scler 2008; 9: 168-172.

23. Wasson J., Keller A., Rubenstein L.; Dartmouth Primary Care COOP Project. Benefits and obstacles of health status assesment in ambulatory settings: the clinicians point of view. Med Care 1992; 30: MS42-MS49. 